\title{
The residual effects of bensulfuron-methyl on growth and photosynthesis of soybean and peanut
}

\author{
W.C. SU, , L.L. SUN ${ }^{*, \#, ~ Y . H . ~ G E *, ~ R . H . ~ W U ~}{ }^{*,+}$, H.L. XU ${ }^{*,+}$, and C.T. LU* \\ Institute of Plant Protection, Henan Academy of Agricultural Sciences; Henan Key Laboratory of Crop Pest Control, \\ IPM Key Laboratory in Southern Part of North China for Ministry of Agriculture. Zhengzhou 450 002, China*
}

\begin{abstract}
The effects of various concentrations of bensulfuron-methyl residues (BSM, 0-500 $\mu \mathrm{g} \mathrm{kg}^{-1}$ ) on the growth and photosynthesis of soybean and peanut were studied. Shoot length, root length, root-to-shoot ratio, and biomass of soybean and peanut seedlings declined with the increase of BSM residue concentrations. As the concentration of BSM increased, SPAD value, net photosynthetic rate, stomatal limitation, stomatal conductance, and transpiration rate also declined with varying extent, but dark respiration rate and intercellular $\mathrm{CO}_{2}$ concentration increased gradually. PSII maximum quantum yield, actual quantum yield, and electron transport rate were significantly reduced by the BSM residues in soil, and the reduction was mostly attributed to the decrease in photochemical quenching coefficient. The results showed that photosynthesis in both crops was limited by nonstomatal factors. The residues of BSM caused reversible damage in PSII reaction centers and decrease the proportion of available excitation energy used for photochemistry.
\end{abstract}

Additional key words: Arachis hypogaea; chlorophyll fluorescence; gas exchange; Glycine max (Linn.) Merr.; phytotoxicity; relative chlorophyll content.

\section{Introduction}

Bensulfuron-methyl [BSM, 2-(4,6-dimethoxypyrimidin2-carbamoylsulfamoyl)-o-toluic acid methyl ester], discovered by the DuPont Co. in the late 1970s, is a type of sulfonylurea herbicide, characterized by broad-spectrum weed control at very low use rates (30-100 $\left.\mathrm{g} \mathrm{ha}^{-1}\right)$, high herbicidal activity, good crop selectivity, and low mammalian toxicity (Brown 1990, Brusa et al. 2001, Sabater et al. 2002). All these characteristics make sulfonylurea herbicides such as BSM an ideal substitute for other older herbicides (Pimentel et al. 1991). The use of BSM in southeast China, California, Japan, and many other areas in the world as a herbicide in rice paddies has steadily increased over the past several years (Sarmah et al. 1998, Sabater et al. 2002), making great contributions to crop protection and production. However, BSM is neither particularly volatile nor photodegradable (Boschin et al. 2003, Si et al. 2004) and therefore may persist for a long time (over $100 \mathrm{~d}$ ) when applied under specific climatic and/or soil conditions (Blair and Martin 1998) and can be leached into the environment or its residues may damage other crops in the rotation (Si et al. 2004).

Crop rotation is common in China. For example, in most wheat-growing areas of the country, wheat is rotated with peanut, soybean, etc. Over large cultivated tracts in southern China, farming is even more intensive and consists of three crops a year: wheat, rice, and soybean (in autumn, after rice). In some areas in the south, owing to recent droughts, a rotation of rice with peanut has been promoted vigorously to boost the production of food grains as well as of edible oil.

\footnotetext{
Received 6 January 2017, accepted 6 March 2017, published as online-first 8 April 2017.

+Corresponding authors; phone/fax: +86-371-65731962, e-mails: renhai.wu@163.com, xuhongle86@126.com

Abbreviations: ALS - acetolactate synthase; a.i. - active ingredient; BSM - bensulfuron-methyl; Chl - chlorophyll; $C_{\mathrm{i}}$ - intercellular $\mathrm{CO}_{2}$ concentration; $E$ - transpiration rate; ETR - electron transport rate; $\mathrm{F}_{\mathrm{m}}$ - maximum fluorescence yield of the dark-adapted state; $\mathrm{F}_{0}$ - minimal fluorescence yield of the dark-adapted state; $\mathrm{F}_{\mathrm{v}}$ - variable fluorescence; $\mathrm{F}_{\mathrm{v}} / \mathrm{F}_{\mathrm{m}}$ - maximum quantum yield of PSII photochemistry; $g_{\mathrm{s}}$ - stomatal conductance; $\mathrm{L}_{\mathrm{s}}$ - stomatal limitation; LSD - least significant difference; $P_{\mathrm{N}}-$ net photosynthetic rate; qP - photochemical quenching coefficient; R:S - root-to-shoot ratio; $\mathrm{SDM}$ - shoot dry mass; $R_{\mathrm{D}}$ - dark respiration rate; RDM - root dry mass; SD - standard deviation; TDM - total dry mass; ФPSII - the actual quantum yield of PSII.

Acknowledgements: This study was supported by the Special Fund for Agro-scientific Research in the Public Interest (201203098), Science and Technology Project of Henan Province (162102110004). We are grateful to the anonymous reviewers for their valuable comments and suggestions.

\#These authors contributed equally to this work.
} 
A great deal of research has been conducted on the adsorption, degradation, and leaching of BSM in soils and its photolysis on soil surface (Saeki and Toyota 2004, Si et al. 2004, Zhu et al. 2005, Luo et al. 2008, Lin et al. 2010, Lin et al. 2012), including the residual phytotoxicity of sulfonylureas to rotation crops, such as maize, sunflower, sugar beet, and dry beans (Anderson and Humburg 1987, Curran et al. 1991). Zhang et al. (2016) reported that residual BSM mainly affected plant height, leaf width, and the activity of amylase and peroxidase, but had little effect on the physiological activity in tobacco. Ye et al. (2005) found that residual BSM inhibited root length in rape. Su et al. (2016) reported that plant height, root length, and net photosynthetic rate of maize seedlings decreased with increased concentrations of BSM residue.

BSM acts by inhibiting the enzyme acetolactate synthase (ALS), which is involved in the synthesis of branched-chain amino acids, leading to the cessation of cell division and of subsequent growth processes in plants. Although photosynthesis is not a major target of herbicides, which inhibit ALS, changes in photosynthesis

\section{Materials and methods}

Plant material and herbicide: The soil used in this study was the top soil $(0-10 \mathrm{~cm})$ collected from Yuanyang, in Henan province, China. The soil ( $\mathrm{pH} \mathrm{8.4,} \mathrm{soil:water} \mathrm{ratio}$ of 1:2.5, w/v), which contained $5.5 \mathrm{~g}$ (organic matter) $\mathrm{kg}^{-1}$, $29.8 \mathrm{mg}$ (available N) $\mathrm{kg}^{-1}, 6.5 \mathrm{mg}$ (available P) $\mathrm{kg}^{-1}$, and $78.3 \mathrm{mg}$ (available $\mathrm{K}) \mathrm{kg}^{-1}$ - measured according to the method described by Bao (2000) - was air-dried and passed through a 2-mm sieve to remove debris and stones.

Soybean (Glycine max (Linn.) Merr., cv. Xudou 18) and peanut (Arachis hypogaea, cv. Yuhua 15) were selected as the test species. Seeds of soybean and peanut were pregerminated for $24 \mathrm{~h}$ at $25^{\circ} \mathrm{C}$ prior to sowing by placing the seeds in Petri dishes on wet paper towels and keeping the dishes in darkness. BSM (98.5\% pure) was purchased from Hangzhou Tianyi Pesticide Manufactory, Zhejiang province, China.

Soil treatment and culture conditions: Stock solutions of BSM were prepared by placing a known quantity of BSM in approximately $50 \mathrm{~mL}$ of acetone and then diluting with water to the 1-L mark in a volumetric flask (Eliason et al. 2004). Standard solutions were created from the stock solutions to produce solutions with concentrations of 0.5 , 1.5 , and $2.5 \mathrm{mg}$ of active ingredient (a.i.) $\mathrm{L}^{-1}(\mathrm{BSM})$. Soil samples (each $200 \mathrm{~g}$ ) were placed into pots $(70 \mathrm{~mm}$ tall and $83 \mathrm{~mm}$ in diameter) and $40 \mathrm{~mL}$ of the standard solution was added to the untreated soil to produce concentrations of BSM up to two or four times those achieved by following the recommended field application rate [74 $\mu \mathrm{g}($ a.i. $\left.) \mathrm{kg}^{-1}\right]$. This resulted in concentrations of 100 , 300 , and $500 \mu \mathrm{g}\left(\right.$ a.i. of BSM) $\mathrm{kg}^{-1}$ (soil). Throughout the paper, the concentrations of BSM was referred to the concentrations of its active ingredient. For the control, parameters were detected in plants treated with herbicides (Sousa et al. 2014). Xia et al. (2006) found that these parameters were inhibited to various degrees upon imazaquin application. Sousa et al. (2014) reported that the organs of photosynthesis in rice may be damaged before visible injury by imidazolinone, lowering the photosynthesis capabilities of the crop. Tomar et al. (2015) reported that anthracene lowered the performance index of PSII in soybean significantly. Imazapic residues in soil inhibited the growth of wheat seedlings and significantly reduced the rate of photosynthesis in wheat (Su et al. 2013).

Although some information is available on the toxicity of sulfonylurea herbicides to weeds and crops (French and Buckley 2008, Kleter et al. 2011, Muszynski et al. 2014), the toxic effects of BSM residues on soybean and peanut have been hardly investigated. In order to fill this research gap, the objective of this study was to understand the response of soybean and peanut to BSM residue by assessing its potential phytotoxicity through examining photosynthesis characteristics so as to provide a theoretical basis for practical use of BSM in rice or wheat rotations.

$50 \mathrm{~mL}$ of distilled water was added to the untreated soil. The soil samples were then manually mixed to ensure uniform distribution of the added BSM throughout the soil and allowed to equilibrate for $24 \mathrm{~h}$. Three pregerminated seeds of soybean or two of peanut, of similar size and comparable length of the radicle, were selected and placed onto the soil surface and covered with a small amount of soil (a layer approximately $0.5 \mathrm{~cm}$ thick), which was lightly packed. The pots were watered daily to $20 \%$ of soil moisture content by adding distilled water to reach a predetermined mass. The seedlings were grown in a growth chamber under controlled conditions $\left[12 \mathrm{~h}\right.$ of light at $27^{\circ} \mathrm{C}$ alternating with $12 \mathrm{~h}$ of darkness at $25^{\circ} \mathrm{C}$; light intensity of $150 \mu \mathrm{mol}\left(\right.$ photon) $\mathrm{m}^{-2} \mathrm{~s}^{-1}$; relative humidity of $70-75 \%$ ].

Growth parameters: After $14 \mathrm{~d}$ of growth, plant height and root length of soybean and peanut seedlings were measured and recorded. Each plant was separated into its roots and shoots. These samples were placed in an oven at $80^{\circ} \mathrm{C}$ for $48 \mathrm{~h}$ before the dry mass of each seedling component was recorded. The root-to-shoot ratio (R:S) was calculated from the shoot dry mass (SDM) and root dry mass (RDM), total dry mass (TDM) being the sum of RDM and SDM.

Relative chlorophyll (Chl) content and gas exchange: After $14 \mathrm{~d}$, five to ten successive readings (depending on the area) in SPAD units were taken by a Chl meter SPAD502 (Konica Minolta Camera Co. Ltd., Japan) across the whole surface of leaves, taking one leaf at a time. Net photosynthetic rate $\left(P_{\mathrm{N}}\right)$, stomatal conductance $\left(g_{\mathrm{s}}\right)$, intercellular $\mathrm{CO}_{2}$ concentration $\left(C_{\mathrm{i}}\right)$, and transpiration rate $(E)$ of single leaves were measured from the central part of 
the first young, fully mature, healthy leaf using a portable photosynthesis system ( $L i-6400$; Li-Cor Inc., Lincoln, NE, USA). The $\mathrm{CO}_{2}$ concentration, temperature, and light intensity in the leaf chamber were kept at $400 \mu \mathrm{mol} \mathrm{mol}^{-1}$, $28 \pm 0.5^{\circ} \mathrm{C}$, and $150 \mu \mathrm{mol}$ (photon) $\mathrm{m}^{-2} \mathrm{~s}^{-1}$, respectively. Stomatal limitation was calculated as $\mathrm{L}_{\mathrm{s}}=1-C_{\mathrm{i}} / C_{\mathrm{a}}$, where $C_{\mathrm{a}}$ is the ambient $\mathrm{CO}_{2}$ concentration. Each treatment was replicated three times. Dark respiration rate $\left(R_{\mathrm{D}}\right)$ was measured with the photosynthetic system after placing the leaves in darkness for $2 \mathrm{~min}$. Individual leaves were irradiated at a PPFD of $0 \mu \mathrm{mol} \mathrm{m} \mathrm{m}^{-2} \mathrm{~s}^{-1}$ until a steady state $P_{\mathrm{N}}$ was reached.

Chl fluorescence was measured simultaneously with an auxiliary attachment to $\mathrm{Li}-6400$ ( $\mathrm{Li}-6400-40$ leaf chamber fluorometer). After dark adaptation of samples for $1 \mathrm{~h}$, minimal fluorescence $\left(\mathrm{F}_{0}\right)$ was measured with weak modulated irradiation $\left[<0.1 \mu \mathrm{mol}\right.$ (photon) $\left.\mathrm{m}^{-2} \mathrm{~s}^{-1}\right]$. A $600-\mathrm{ms}$ saturating flash $\left[>7,000 \mu \mathrm{mol}\right.$ (photon) $\left.\mathrm{m}^{-2} \mathrm{~s}^{-1}\right]$ was applied to determine the maximum $\mathrm{Chl}$ fluorescence yield $\left(\mathrm{F}_{\mathrm{m}}\right)$. Variable fluorescence $\left(F_{v}\right)$ was calculated as $F_{v}=F_{m}-F_{0}$. The maximum quantum yield of PSII photochemistry

\section{Results}

Growth: The effect of BSM residues at its different doses on the growth of soybean and peanut is shown in Fig. 1. The results clearly demonstrated that roots were quite sensitive to the residue of BSM. The greater effect of BSM residues was found in the soybean seedlings. Shoot length, root length, and dry mass of both soybean and peanut seedlings decreased with increase in BSM residue concentrations.

Dry mass decreased with the increase in BSM residue concentrations. At BSM concentrations of $100-500 \mu \mathrm{g} \mathrm{kg}^{-1}$ (soil), shoot length (Fig. 1A) and R:S (Fig. $1 F$ ) of soybean seedling were not significantly different from their corresponding values in the control. At 300 and $500 \mu \mathrm{g} \mathrm{kg}^{-1}$, SDM, RDM, and TDM of soybean seedling decreased significantly (Fig. $1 C-E$ ). The effect of BSM residue was greater on root length of both crops: root length was significantly reduced in both at all concentrations of BSM when compared to that in the control (Fig. $1 B$ ). In peanut, shoot length at $500 \mu \mathrm{g} \mathrm{kg}^{-1}$ decreased significantly, by as much as $21 \%$ (Fig. 1A). Compared with the untreated controls, RDM at 100, 300, and $500 \mu \mathrm{g} \mathrm{kg}^{-1}$ decreased significantly, by 18,26 , and $29 \%$, respectively (Fig. $1 D$ ). However, no significant difference was found in the values of SDM, TDM, and R:S at any of the BSM residue concentrations (Fig. 1C,E,F).

Relative Chl content and gas exchange: SPAD readings have been shown to be strongly correlated to leaf Chl content (Marquard and Tipton 1987, Markwell et al. 1995, Wang et al. 2004). At a low residue concentration of BSM $\left(100 \mu \mathrm{g} \mathrm{kg}^{-1}\right)$, SPAD values of soybean and peanut seedling leaves were significantly lower than those in the
$\left(\mathrm{F}_{\mathrm{v}} / \mathrm{F}_{\mathrm{m}}\right)$ was calculated as $\mathrm{F}_{\mathrm{v}} / \mathrm{F}_{\mathrm{m}}=\left(\mathrm{F}_{\mathrm{m}}-\mathrm{F}_{0}\right) / \mathrm{F}_{\mathrm{m}}$; the actual quantum yield of PSII ( $\left.\Phi_{\text {PSII }}\right)$ was calculated as $\Phi_{\text {PSII }}=$ $\left(\mathrm{F}_{\mathrm{m}}{ }^{\prime}-\mathrm{F}_{\mathrm{s}}\right) / \mathrm{F}_{\mathrm{m}}{ }^{\prime}$; and photochemical quenching coefficient $\left(\mathrm{q}_{\mathrm{P}}\right)$ was calculated as $\mathrm{q}_{\mathrm{P}}=\left(\mathrm{F}_{\mathrm{m}}{ }^{\prime}-\mathrm{F}_{\mathrm{s}}\right) /\left(\mathrm{F}_{\mathrm{m}}{ }^{\prime}-\mathrm{F}_{0}{ }^{\prime}\right)$. The electron transport rate (ETR) was calculated as ETR = $\Phi_{\text {PSII }} \times$ PAR $\times 0.5 \times 0.84$, where PAR is the intensity $(\mu \mathrm{mol}$ $\mathrm{m}^{-2} \mathrm{~s}^{-1}$ ) of photosynthetically active radiation incident on the sample, 0.5 is the proportion of light energy assigned to PSII, and 0.84 denotes that $84 \%$ of the incident light is absorbed by leaves (Genty et al. 1989, Lazár 2015). All these calculations are performed automatically by the instrument.

Statistical analysis: All the data presented here are the mean values of two independent experiments with three replications and are given as mean \pm standard deviation (SD). All data were subjected to one-way analysis of variance (ANOVA) with SPSS (Version 17.0, SPSS Inc.). The differences between treatments were separated by the method of least significant difference $(L S D)$ at 0.05 probability level $(P<0.05)$.

control, the extent of decrease being 13 and 18\%, respectively. As the BSM residue concentration increased, SPAD values decreased even further: the decrease at 300 and 500 $\mu \mathrm{g} \mathrm{kg}^{-1}$ in soybean was 19 and $24 \%$, respectively; in peanut, the corresponding values were 29 and $30 \%$ (Fig. $3 E$ ).

As the residue concentration of BSM increased, $P_{\mathrm{N}}$ decreased significantly in both soybean and peanut in all the treatments (Fig. 2A), compared with the control: the extent of decrease was $38-62 \%$ in soybean and $22-52 \%$ in peanut.

$R_{\mathrm{D}}$ in soybean and peanut leaves rose gradually with the residue concentration of BSM. Compared with the untreated controls, $R_{\mathrm{D}}$ of soybean leaves at 300 and $500 \mu \mathrm{g}$ $\mathrm{kg}^{-1}$ increased significantly, by 87 and $144 \%$, respectively, and that of peanut leaves at 100,300 , and $500 \mu \mathrm{g} \mathrm{kg}^{-1}$ increased significantly, by 64,158 , and $197 \%$, respectively (Fig. 2B).

The application of BSM increased $C_{\mathrm{i}}$ to varying degrees in soybean and peanut (Fig. $2 C$ ). Compared with the control, $C_{\mathrm{i}}$ in soybean was not significantly different at $100-300 \mu \mathrm{g} \mathrm{kg}^{-1}$ but increased significantly at $500 \mu \mathrm{g} \mathrm{kg}^{-1}$; $C_{\mathrm{i}}$ of peanut leaves at 100,300 , and $500 \mu \mathrm{g} \mathrm{kg}^{-1}$ increased significantly, by 28,31 , and $38 \%$, respectively.

Concerning $\mathrm{L}_{\mathrm{s}}$, its value decreased in both crops as the residue concentration of BSM increased (Fig. 2D). Although the difference between soybean and the control was not significant at $100 \mu \mathrm{g} \mathrm{kg}^{-1}$, the differences were significant at $300-500 \mu \mathrm{g} \mathrm{kg}^{-1}$. In peanut, the decrease was not significant at $100-300 \mu \mathrm{g} \mathrm{kg}^{-1}$ but it was significant at $500 \mu \mathrm{g} \mathrm{kg}^{-1}$ (the extent of decrease was $33 \%$ ). Thus, the pattern of changes in $L_{s}$ in the two species was just the opposite of that seen in $C_{\mathrm{i}}$. 


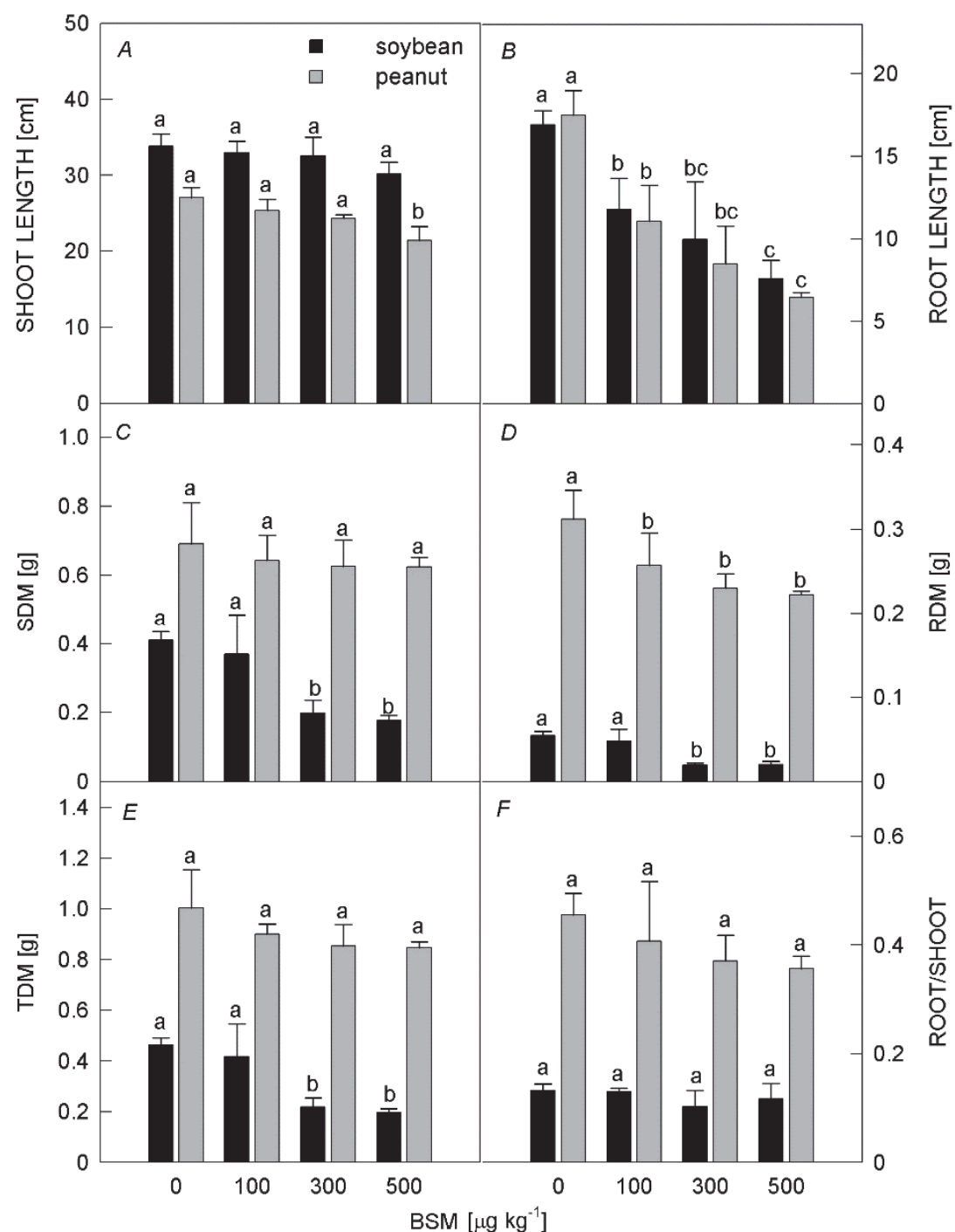

Fig. 1. (A) Shoot length, $(B)$ root length, $(C)$ shoot dry mass $(\mathrm{SDM}),(D)$ root dry mass (RDM), $(E)$ total dry mass (TDM), and $(F)$ root/shoot ratio of soybean and peanut seedlings under different soil concentrations $\left(0,100,300\right.$, and $\left.500 \mu \mathrm{g} \mathrm{kg}{ }^{-1}\right)$ for the herbicide bensulfuron-methyl. Values are means of four replicates \pm SD. Means of each parameter were analyzed using Duncan's multiple range test to check the significance of difference between treatments. Columns marked with different lowercase letters indicate a significant difference between treatments at $P<0.05$.
As the residue concentration of BSM increased, $g_{\mathrm{s}}$ of soybean leaves decreased. The difference in $g_{\mathrm{s}}$ between the treated plants and the control was not significant at $100 \mu \mathrm{g}$ $\mathrm{kg}^{-1}$ but it was significant at 300 and $500 \mu \mathrm{g} \mathrm{kg}$. Compared with the control, $g_{\mathrm{s}}$ of peanut leaves in 100,300 , and $500 \mu \mathrm{g} \mathrm{kg}^{-1}$ decreased by 40,52 , and $74 \%$, respectively (Fig. 2E).

As shown (in Fig. 2F), $E$ decreased significantly in both crops as the residue concentration of BSM increased. The decrease at 100,300 , and $500 \mu \mathrm{g} \mathrm{kg}^{-1}$ in soybean was 40,56 , and $58 \%$, respectively; in peanut, the corresponding values were 30,53 , and $67 \%$. The pattern of changes in $E$ in each crop thus essentially matched to that in $g_{\mathrm{s}}$, which also suggests that BSM affected photosynthesis in soybean and peanut significantly.

\section{Discussion}

Herbicide persistence is an important fact in crop production since residues can potentially injure sensitive
Chl fluorescence parameters, such as $\mathrm{F}_{\mathrm{v}} / \mathrm{F}_{\mathrm{m}}, \Phi_{\mathrm{PSII}}, \mathrm{q}_{\mathrm{P}}$, and ETR in both crops decreased as the residue concentrations of BSM increased (Fig. 3A-D). Compared with the untreated controls, $\mathrm{F}_{\mathrm{v}} / \mathrm{F}_{\mathrm{m}}$ and $\Phi_{\mathrm{PSII}}$ of soybean leaves at $100-500 \mu \mathrm{g} \mathrm{kg}^{-1}$ decreased by $2-6 \%$ and $16-28 \%$, respectively, $\mathrm{q}_{\mathrm{P}}$ and ETR at 300 and $500 \mu \mathrm{g} \mathrm{kg}^{-1}$ were also significantly lower, by $13-18 \%$ and $24-25 \%$, respectively. In peanut, $\mathrm{F}_{\mathrm{v}} / \mathrm{F}_{\mathrm{m}}$ was significantly lower at $300-500 \mu \mathrm{g} \mathrm{kg}^{-1}$ by $1-2 \%, \Phi_{\text {PSII }}$ decreased significantly at $100-500 \mu \mathrm{g} \mathrm{kg}^{-1}$ by $4-7 \%$, and $\mathrm{q}_{\mathrm{P}}$ and ETR were significantly lower only at $500 \mu \mathrm{g} \mathrm{kg}^{-1}$ by $8 \%$. These results showed that fluorescence parameters of soybean were more sensitive than those of peanut to BSM residue.

crops grown in rotation (Riddle et al. 2013). A laboratory test helps to predict potential herbicide residue problems 
so that proper decisions can be taken about crop rotation, herbicide selection, planting date, and other cultural practices. In the present study, the residue of BSM lowered plant height and root length in both soybean and peanut significantly, the extent of decrease being directly proportional to the concentration of BSM added to the soil. Roots proved to be more sensitive to the residue of BSM than shoots, probably because the seedlings absorbed it through their roots and then transported it to the stems and leaves. As the concentration of the residual BSM increased, SDM, RDM, and TDM declined gradually. The root-to-shoot ratio in both soybean and peanut decreased as BSM concentration increased, showing that BSM had a greater effect on below-ground biomass than on aboveground biomass. These results agree with analysis of Lou et al. (2005) that BSM inhibition of root length is greater than that of plant height. Our results showed that BSM residue strongly inhibited the growth of soybean and peanut seedlings, and that soybean was more sensitive to BSM residue.

Stress factors, such as temperatures too high or too low, insufficient light, and heavy metals are known to affect photosynthesis (Berry and Bjorkman 1980, Burzyski and Klobus 2004, Kosobrukhov et al. 2004, González-Naranjo et al. 2015, Tomar et al. 2015). Some herbicides can also affect the growth and development of crops by impairing

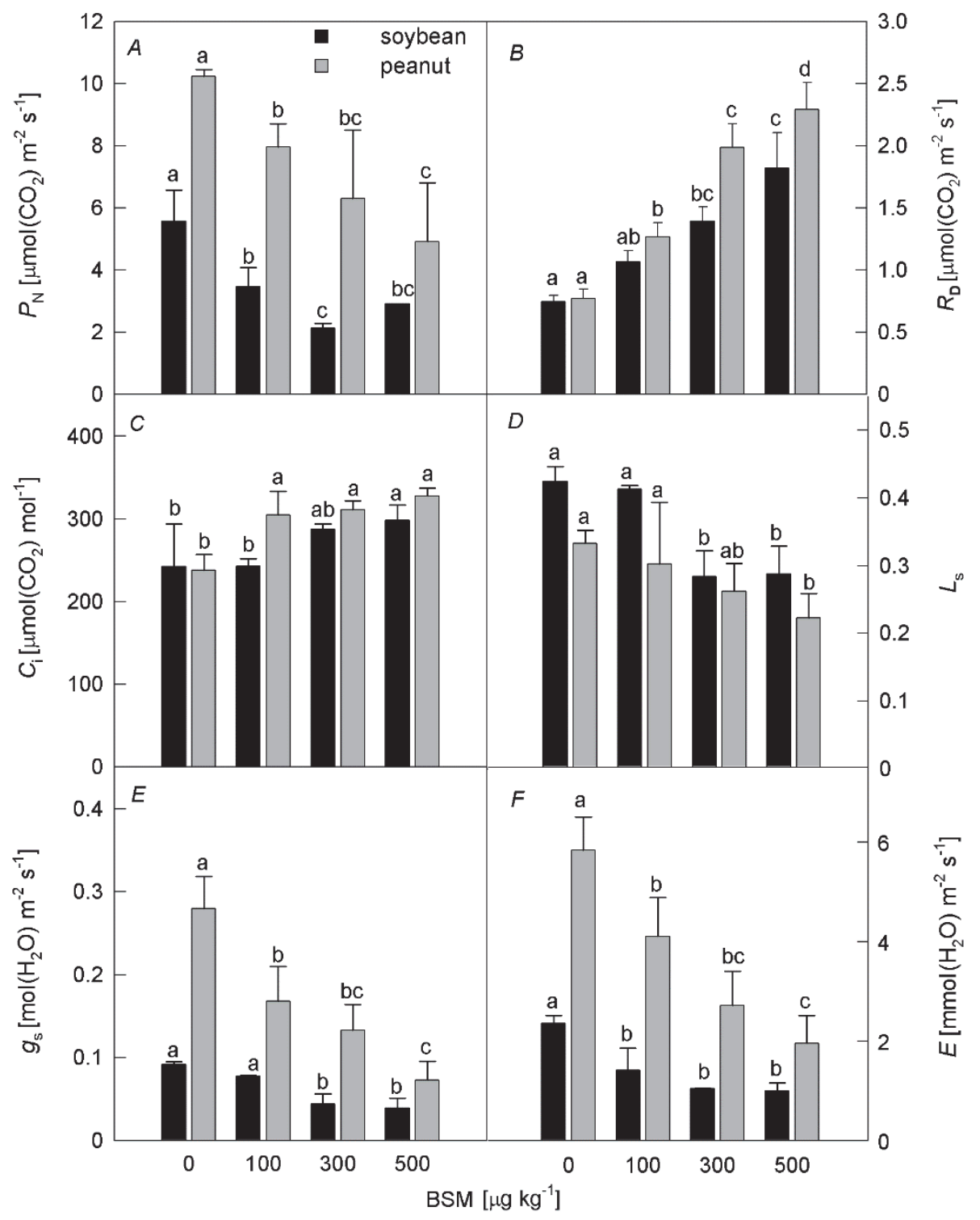

Fig. 2. $(A)$ Net photosynthetic $\left(P_{\mathrm{N}}\right),(B)$ dark respiration rate $\left(R_{\mathrm{D}}\right),(C)$ intercellular $\mathrm{CO}_{2}$ concentration $\left(C_{\mathrm{i}}\right),(D)$ stomatal limitation $\left(\mathrm{L}_{\mathrm{s}}\right)$, $(E)$ stomatal conductance $\left(g_{\mathrm{s}}\right)$, and $(F)$ transpiration rate $(E)$ of soybean and peanut seedlings under different soil concentrations $(0,100$, 300 , and $500 \mu \mathrm{g} \mathrm{kg}^{-1}$ ) for the herbicide bensulfuron-methyl. Error bars show standard deviation $(n=4)$. Different letters on the bars indicate significant differences at $P<0.05$, according to Duncan's multiple range test. 


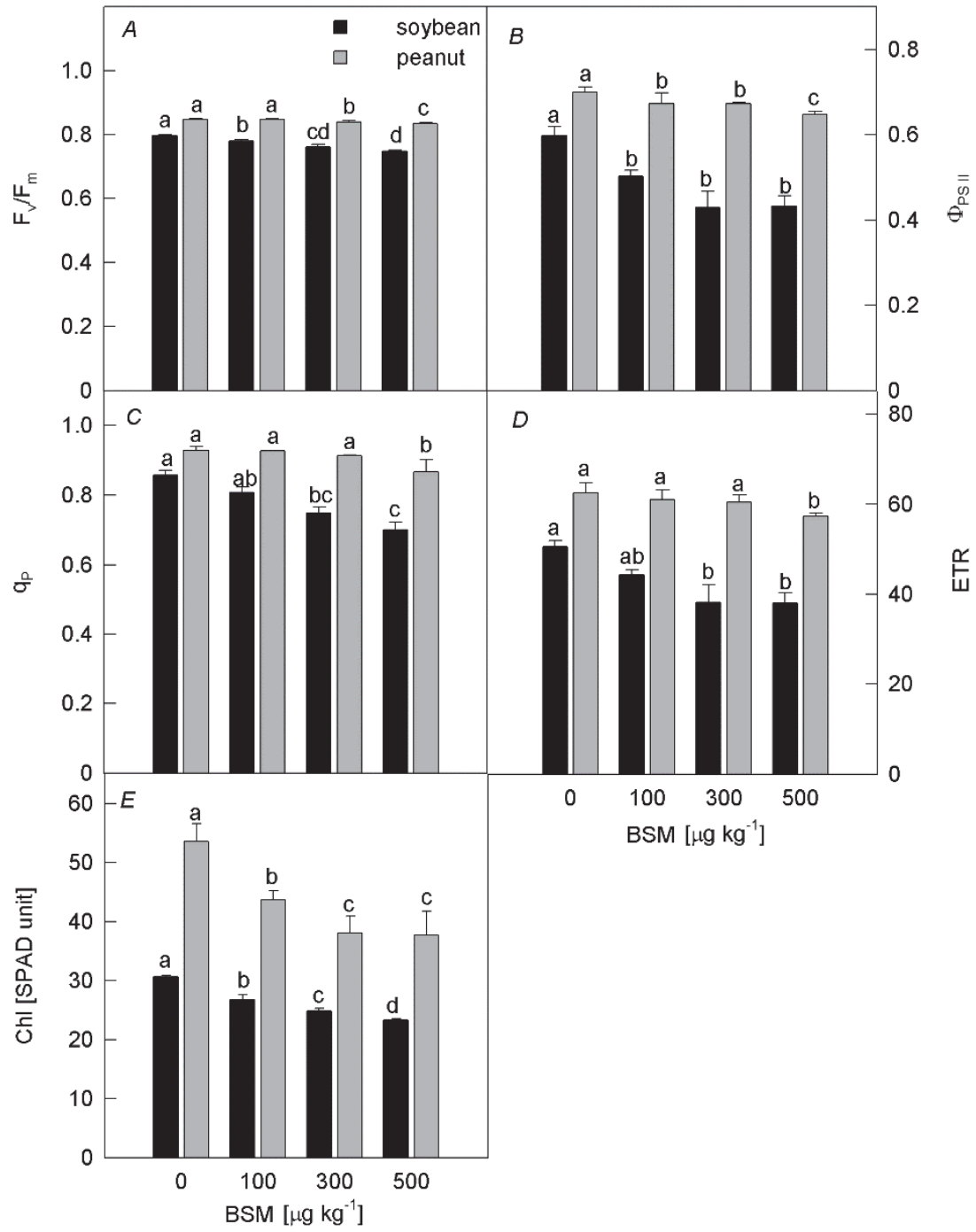

Fig. 3. (A) Maximum quantum yield of PSII photochemistry $\left(\mathrm{F}_{\mathrm{v}} / \mathrm{F}_{\mathrm{m}}\right),(B)$ actual quantum yield of PSII under actinic light of $150 \mu \mathrm{mol}$ (photon) $\mathrm{m}^{-2} \mathrm{~s}^{-1}$ (ФPSII), $(C)$ photochemical quenching coefficient $\left(\mathrm{q}_{\mathrm{P}}\right)$, $(D)$ electron transport rate (ETR), (E) SPAD value of soybean and peanut seedlings under different soil concentrations $(0,100,300$, and $500 \mu \mathrm{g}$ $\mathrm{kg}^{-1}$ ) for the herbicide bensulfuron-methyl. Error bars show standard deviation $(n=4)$. Different letters on the bars indicate significant differences at $P<0.05$, according to Duncan's multiple range test. normal physiological parameters or functions. For example, flumioxazin can cause a sharp drop in $P_{\mathrm{N}}$ and $g_{\mathrm{s}}$ in grapes (Bigot et al. 2007). Leaf SPAD values are a direct reflection of the relative leaf $\mathrm{Chl}$ and are positively correlated to $\mathrm{Chl}$ content. Chl content is closely related to $P_{\mathrm{N}}$, and herbicides have been shown to reduce the content of photosynthetic pigments and $P_{\mathrm{N}}$ in leaves ( $\mathrm{Su}$ et al. 2013). Both $P_{\mathrm{N}}$ and Chl content showed a similar trend, and the decrease in Chl might also be one of the major reasons for the decrease in $P_{\mathrm{N}}$ in the present experiment. The decrease in $P_{\mathrm{N}}$ and the increase in $R_{\mathrm{D}}$ in both the crops suggest that increased respiration could be a mechanism to alleviate the damage to photosynthesis caused by BSM (Catriona et al. 2002, Ohe et al. 2005, Sun et al. 2010).

Farquhar and Sharkey (1982) examined whether stomatal or nonstomatal factors were the main cause of reduced $P_{\mathrm{N}}$ as can be judged by the changing pattern of both $C_{\mathrm{i}}$ and $\mathrm{L}_{\mathrm{s}}$. If both $C_{\mathrm{i}}$ and $P_{\mathrm{N}}$ decreased, accompanied by an increase in $\mathrm{L}_{\mathrm{s}}$, the decrease of $P_{\mathrm{N}}$ was mainly caused by stomatal limitation. On the contrary, when $P_{\mathrm{N}}$ decreased, $C_{\mathrm{i}}$ may increase or be constant despite lower $g_{\mathrm{s}}$, and is accompanied by a decrease in $\mathrm{L}_{\mathrm{s}}$. Thus it is the photosynthetic activity of mesophyll cells rather than $g_{\mathrm{s}}$ that was regarded as the critical factor in reducing $P_{\mathrm{N}}$.

According to the above theory, the residual effects of BSM resulted in decreased $P_{\mathrm{N}}$ and $\mathrm{L}_{\mathrm{s}}$ and increased $C_{\mathrm{i}}$, indicating that photosynthesis in both crops was limited by nonstomatal factors. These results were consistent with earlier findings showing that the suppression of $P_{\mathrm{N}}$ induced by cyazofamid was mostly due to nonstomatal factors (Xia et al. 2006).

In order to further investigate the nonstomatal factors involved, Chl fluorescence parameters were analyzed. Chl fluorescence is a major technique for detecting and analyzing photosynthesis, which can provide a wealth of information on the photosystem and the electron transfer activities (Krause and Weis 1991). Earlier studies have shown that herbicides damage the PSII complex, block photosynthetic electron transfer, reduce $\mathrm{F}_{\mathrm{v}} / \mathrm{F}_{\mathrm{m}}, \Phi_{\mathrm{PSII}}$, and $\mathrm{q}_{\mathrm{P}}$ significantly, and increase the nonphotochemical quenching coefficient in wheat leaves (Wang et al. 2011). The residual BSM caused significant decreases in $\mathrm{F}_{\mathrm{v}} / \mathrm{F}_{\mathrm{m}}$, 
$\Phi_{\text {PSII, }}$ q , and ETR in both crops. The effect on these parameters indicates that the residues of BSM caused reversible destruction in PSII reaction centers. A decrease in $\mathrm{q}_{\mathrm{P}}$ indicated a higher proportion of closed PSII reaction centers, i.e., an increase in the proportion of the reduced state of $\mathrm{Q}_{\mathrm{A}}$, which probably leads to a decrease in the proportion of available excitation energy used for photochemistry (Genty et al. 1989). Dayan and Zaccaro (2012) observed a decreased ETR in cucumber plants exposed to light and bentazon. An increase in the non-

\section{References}

Anderson R.L., Humburg N.E.: Field duration of chlorsulfuron bioactivity in the central Great Plains. - J. Environ. Qual. 16: 263-266, 1987.

Bao S.D.: [Soil and Agricultural Chemistry Analysis.] Pp. 25108. Agricult. Publ., Beijing 2000. [In Chinese]

Berry J., Björkman O.: Photosynthetic response and adaptation to temperature in higher plants. - Annu. Rev. Plant Physio. 31: 491-543, 1980.

Bigot A., Fontaine F., Clément C. et al:: Effect of the herbicide flumioxazin on photosynthetic performance of grapevine (Vitis vinifera L.). - Chemosphere 67: 1243-1251, 2007.

Blair A.M., Martin D.: A review of the activity, fate and mode of action of sulfonylures herbicides. - J. Pestic. Sci. 22: 195-219, 1998.

Boschin G., D'Agostina A., Arnoldi A. et al.: Biodegradation of chlorsulfuron and metsulfuron-methyl by Aspergillus niger in laboratory conditions. - J. Environ. Sci. Heal. B 38: 737-746, 2003.

Brown H.M.: Mode of action, crop selectivity, and soil relations of the sulfonylurea herbicides. - Pestic. Sci. 29: 263-281, 1990.

Brusa T., Ferrari F., Bolzacchini E. et al.: Study on the microbiological degradation of bensulfuronmethyl. - Ann. Microbiol. 51: 189-200, 2001.

Burzyński M., Kłobus G.: Changes of photosynthetic parameters in cucumber leaves under $\mathrm{Cu}, \mathrm{Cd}$, and $\mathrm{Pb}$ stress. Photosynthetica 42: 505-510, 2004.

Curran W.S., Knake E.L., Liebl R.A.: Corn (Zea mays) injury following use of clomazone, chlorimuron, imazaquin, and imazethapyr. - Weed Technol. 5: 539-544, 1991.

Dayan F.E., Zaccaro M.L.M.: Chlorophyll fluorescence as a marker for herbicide mechanisms of action. - Pestic. Biochem. Physiol. 102: 189-197, 2012.

Eliason R., Schoenau J., Szmigielski A. et al.: Phytotoxicity and persistence of flucarbazone-sodium in soil. - Weed Sci. 52: 857-862, 2004.

Farquhar G., Sharkey T.: Stomatal conductance and photosynthesis. - Annu. Rev. Plant Physio. 33: 317-345, 1982.

French K., Buckley S.: The effects of the herbicide metsulfuronmethyl on litter invertebrate communities in a coastal dune invaded by Chrysanthemoides monilifera spp. rotundata. Weed Res. 48: 266-272, 2008.

Genty B., Briantais J.M., Baker N.R.: The relationship between the quantum yield of photosynthetic electron transport and quenching of chlorophyll fluorescence-- Biochim. Biophys. Acta 990: 87-92, 1989.

González-Naranjo V., Boltes K., Bustamante I. et al.: Environmental risk of combined emerging pollutants in terrestrial environments: chlorophyll $a$ fluorescence analysis. - Environ. photochemical quenching coefficient was observed concomitantly with a drop in $\Phi_{\mathrm{PSI}}, \mathrm{q}_{\mathrm{P}}$, and ETR, confirming that the energy absorbed by the antenna system was not used for photochemical effect in photosynthesis (Maxwell and Johnson 2000, Müller et al. 2001, Roháček 2002).

The accumulation of biomass represents the net effect of carbon assimilation and maintenance. In soybean and peanut, the SDM, RDM, and TDM were significantly reduced by BSM residue concentration, suggesting that growth of was negatively influenced by BSM residue.

Sci. Pollut. Res. 22: 6920-6931, 2015.

Kleter G.A., Unsworth J.B., Harris C.A.: The impact of altered herbicide residues in transgenic herbicide-resistant crops on standard setting for herbicide residues. - Pest Manag. Sci. 67: 1193-1210, 2011.

Kosobrukhov A., Knyazeva I., Mudrik V.: Plantago major plants responses to increase content of lead in soil: Growth and photosynthesis. - Plant Growth Regul. 42: 145-151, 2004.

Krause G., Weis E.: Chlorophyll fluorescence and photosynthesis: the basics. - Annu. Rev. Plant Phys. 42: 313-349, 1991.

Lazár D.: Parameters of photosynthetic energy partitioning. - J. Plant Physiol. 175: 131-147, 2015.

Lin X.Y., Yang Y.Y., Zhao Y.H. et al.: Biodegradation of bensulfuron-methyl and its effect on bacterial community in paddy soils. - Ecotoxicology 21: 1281-1290, 2012.

Lin X.Y., Wang Y., Wang H.L. et al.: Isolation and characterization of a bensulfuron-methyl-degrading strain L1 of Bacillus. - Pedosphere 20: 111-119, 2010.

Lou G.Q., Lv W.Y.., Zhi M.X.: [Studies on safety of Tribenuronmethyl and bensulfuron-methyl and their impact to the content of chlorophyll.] - Chinese Agri. Sci. Bull. 21: 317-320, 2005. [In Chinese]

Luo W., Zhao Y.H., Ding H.T. et al.: Co-metabolic degradation of bensulfuron-methyl in laboratory conditions. - J. Hazard. Mater. 158: 208-214, 2008.

MacinnisNg C.M., Ralph P.J.: Towards a more ecologically relevant assessment of the impact of heavy metals on the photosynthesis of the seagrass, Zostera capricorni. - Mar. Pollut. Bull. 45: 100-106, 2002.

Markwell J., Osterman J.C., Mitchell J.L.: Calibration of the Minolta SPAD-502 leaf chlorophyll meter. - Photosynth. Res. 46: 467-472,1995.

Marquard R.D., Tipton J.L.: Relationship between extractable chlorophyll and an in situ method to estimate leaf greenness. HortScience 22: 13-27, 1987.

Maxwell K., Johnson G.N.: Chlorophyll fluorescence: a practical guide. - J. Exp. Bot. 51: 659-668, 2000.

Müller P., Li X.P., Niyogi K.K.: Non-photochemical quenching. A response to excess light energy. - Plant Physiol. 125: 15581566, 2001.

Muszynski P., Brodowska M., Pabich M. et al.: The sorption and degradation of sulfonylurea herbicides in soils. - Przem. Chem. 93: 531-535, 2014.

Ohe M., Rapolu M., Mieda T. et al:: Decline in leaf photooxidative-stress tolerance with age in tobacco. - Plant Sci. 168: 1487-1493, 2005.

Pimentel D., McLaughlin L., Zepp A. et al.: Environmental and 
economic effects of reducing pesticide use. - BioScience 41: 402-409, 1991.

Riddle R.N., O'Sullivan J., Swanton C.J. et al.: Field and greenhouse bioassays to determine mesotrione residues in soil. - Weed Technol. 27: 565-572, 2013.

Roháček K.: Chlorophyll fluorescence parameters: the definitions, photosynthetic meaning, and mutual relationships. Photosynthetica 40: 13-29, 2002.

Sabater C., Cuesta A., Carrasco R.: Effects of bensulfuronmethyl and cinosulfuron on growth of four freshwater species of phytoplankton. - Chemosphere 46: 953-960, 2002.

Saeki M., Toyota K.: Effect of bensulfuron-methyl (a sulfonylurea herbicide) on the soil bacterial community of a paddy soil microcosm. - Biol. Fert. Soils 40: 110-118, 2004.

Sarmah A.K., Kookana R.S., Alston A.M.: Fate and behaviour of triasulfuron, metsulfuron-methyl, and chlorosulfuron in the Australian soil environment: a review. - Aust. J. Agr. Res. 49: 775-790, 1998.

Si Y.B., Zhou J., Chen H.M. et al.: Photostabilization of the herbicide bensulfuron-methyl by using organoclays. Chemosphere 54: 943-950, 2004.

Sousa C., Pinto J., Martinazzo E. et al.: Chlorophyll $a$ fluorescence in rice plants exposed of herbicides of group imidazolinone. - Planta Daninha 32: 141-150, 2014.

$\mathrm{Su}$ W.C., Ge Y.H., Wu R.H. et al.: [Effects of bensulfuronmethyl residue on photosynthesis traits and chlorophyll fluorescence of cron seedlings.] - J. Maize Sci. 24: 67-74, 2016. [In Chinese]

Su W.C., Sun L.L., Zhang Q. et al.: [Effects of imazapic residues on the growth and photosynthetic parameters of wheat seedlings as succeeding crop.] - J. Triticeae Crops 33: 1226-
1231, 2013. [In Chinese]

Sun R.G., Zhao G.Q., Hu K.J. et al.: [Effect of salinity stress on aboveground dry matter accumulation of oat and photosynthesis at grain filling stage.] - Chinese J. Grassl. 32: 15-20, 2010. [In Chinese]

Tomar R., Sharma A., Jajoo A.: Assessment of phytotoxicity of anthracene in soybean (Glycine max) with a quick method of chlorophyll fluorescence. - Plant Biol. 17: 870-876, 2015.

Wang Q., Chen J., Li Y.: Nondestructive and rapid estimation of leaf chlorophyll and nitrogen status of peace lily using a chlorophyll meter. - J. Plant Nutr. 27: 557-569, 2004.

Wang Z.G., Zhou L.Y., Guo W.S. et al.: [Effects of herbicides on photosynthesis and chlorophyll fluorescence parameters in wheat leaves.] - J. Agro-Environ. Sci. 30: 1037-1043, 2011. [In Chinese].

Xia X.J., Huang Y.Y., Wang L. et al.: Pesticides-induced depression of photosynthesis was alleviated by 24-epibrassinolide pretreatment in Cucumis sativus L. - Pestic. Biochem. Phys. 86: 42-48, 2006.

Ye F.B., Wu Z.H., Dong Y.Y. et al.: [Phytotoxicity of the herbicide bensulfuron- methyl to next-season crop.] - J. Hubei Agri. Sci. 5: 72-73, 2005. [In Chinese]

Zhang G.B., Feng X.J., Zhou X.Y. et al.: Effects of paddy herbicide residues on agronomic traits and physiological metabolism of tobacco. - J. South China Agr. Univ. 37: 41-45, 2016. [In Chinese]

Zhu Y.W., Zhao Y.H., Lin X.Y. et al.: Isolation, characterization and phylogenetic analysis of an aerobic bacterium capable of degrading bensulfuronmethyl. - World J. Microb. Biot. 21: 1195-1200, 2005. 